〔日農医誌 48巻 4 号 625～629頁 1999． 11〕

\title{
平成10年度全共連委託研究報告：
}

\section{農村における骨粗㧞症の集団検診技法と 発症要因に関する研究}

\author{
主任研究者 角 田文 男 \\ (岩手医科大学医学部衛生学公衆衛生学講座教授)
}

1980年以前まで我が国の人口構成は西欧先進諸国に比して老年人口割合が低かったが, 1985年老年人口割合が10\%を超えるとその11年後の1996年には $15 \%$ 超えるという，他の 先進諸国でも類をみない速度で高齢化が進行してきた。農村部と目される地域において は，その傾向が顕著であり，島根や秋田，山形などでは老年人口割合が既に $20 \%$ を回る に至っている。このような人口動向により, 特に農村部では地域保健医療の面で様々な老 年期の退行性疾患が注目されるが，なかでも老年期骨粗鬆症患者の増加は著しく, 同症に よる骨折や疼痛, 寝たきり, さらには QOL（Quality of Life）の低下などが大きな問題 となっている。すなわち加齢とともに全身骨量が減少して骨折の発生率が高まり，寝たき り状態の要因になること, また, 医療費の高騰にもかかわってきていることなどから特に 農村の保健医療福祉上，緊急な対応がせまられるようになった。

骨粗鬆症は，骨量の減少および骨梁構造の悪化により骨の脆弱性がえ進した状態であ り，多くは閉経に伴うエストロゲンの減少による閉経後骨粗鬆症および加齢による生理的 な骨量減少を基本とする老年期骨粗鬆症に分類される。同症の発症には, 成長過程での骨 量獲得の程度, また, 女性における閉経期前後の骨減少, さらに男女での壮年期以降の骨 量減少もしくは骨梁構造の破綻の程度と壮老年期での転倒事故などの有無やその頻度が大 きくかかわるものと考えられており, 予防医学的見地から一生を通じての対策が重要であ る。骨粗鬆症の診断や重症度の判定, また骨粗鬆症のリスクファクターの検索には骨量の 評価が必要不可欠である。従来, 骨量減少の有無は胸腰椎 $\mathrm{X}$ 線写真から定性的に判定さ れてきたが, 最近の骨量測定法の飛躍的な発展によって, 本症の第一次予防や管理に有効 な骨密度や骨強度を高精度, 高感度に数量化できるようになった。しかしこれらの測定法 を用いて骨粗鬆症の集団検診を行うには, 測定機器の器差, 測定部位の問題, 測定時間の 短縮等, いくつかの未解決な課題がある。

本研究では，骨粗鬆症を基本とした農村地区における骨粗鬆症の集団検診技法を確立す る一方, 特に農村部婦人の骨粗鬆症発症に係わる諸要因について検討し, その予防対策と 健康管理に寄与しようとするものである。

\section{分担研究者及び研究機関}

杉村旅（総合病院旭川厚生病院院長）

林雅人 (平鹿総合病院院長)

岡林 義弘（松阪中央総合病院名誉院長）
立身 政信（岩手医科大学医学部衛生学公衆衛 生学講座助教授)

小野田敏行（岩手医科大学医学部衛生学公衆衛 生学講座講師) 


\section{研 究 方 法}

\section{1. 研究対象}

研究対象は，共同研究者の各施設で行う骨量 検診を受診した女性とし，その年齢層は主に 40 〜 59歳とした。対象数は共同研究者の施設全体 でのべ2,000名を目標とした。研究参加施設は 主任研究者抒よび共同研究者の所属する岩手医 科大学医学部衛生学公衆衛生学講座, 総合病院 旭川厚生病院, 平鹿総合病院, 松阪中央総合病 院の 4 施設である。

2 . 研究方法

本研究における集団検診は骨量測定, 体格測 定，採血および問診を基本項目とする。

骨量検診では統一された問診票を用いること とし, 研究担当者の協議によって各問診項目を 検討して作成した。

統一問診票では，1 . 既往歴，2 . 就労状況， 3 . 運動状況, 4. 嗜好品, 5. 食生活状況, 6. 住生活状況の 6 項目に関する質問を検討し て A 4 判 4 枚の自記式の調査票にまとめた。

既往歴に関しては，骨粗鬆症検診を受診する 住民のうち，受診理由として「骨粗鬆症と診断 されたことがあるため」とするものが比較的多 く見受けられやすいことから特に骨粗鬆症に関 する既往歴および治療歴に関して質問項目を設 けた。骨折の既往歴では骨粗琹症でみられる代 表的な骨折について選択式とした。また，骨粗 鬆症によるものかどうかを判定するために，そ の発生年齢や骨折理由を問うことにした。糖尿 病や腎臓病など骨量に影響を与えると考えられ る疾患の既往の有無を尋ねる欄では，具体的な 疾患名を選ぶ形式とし，疾患名の自由記述式の 設問は解析の精度および受診者の負担を考慮し て特に設けなかった。このため，直接的な影響 の考えにくい疾患の既往歴に関する質問はない 調査票となったが，これを補うため，現在治療 中の疾患に関しては自由記述式とした。その 他, 自覚症状として腰背痛, 身長の低下, 円背 の有無について設問を設定した。

対象が女性の場合，性周期や妊娠出産授乳 歴，婦人科疾患の既往歴は骨粗鬆症との関わり
において特に重要であるが，これらについては 答えにくい性質の項目もあることから，初潮時 期, 現在の月経状況, 婦人科疾患, 出産回数, 授乳経験回数について集団として把握可能と考 えられる範囲内でなるべく簡略化を図った。

就労状況は，農村地区を対象として行う検診 票なので，特に農作業の内容についてライフス タイルとの関連を推察可能と考えられる範囲内 で簡易な設問を設定した。

運動状況は, 岩手医科大学医学部衛生学公衆 衛生学講座で今までに行ってきた調査におい て, 特に若い時期の運動が peak bone mass の 増大，その後の運動習慣の形成および骨量の維 持に強い関連が認められたことから，若年期お よび現在のそれぞれについて運動状況を尋ねる 欄を設けた。なお，運動内容に関しては自由記 述式としたが，「散歩」「踊り」などの比較的軽 い運動は本人が一般の運動として捉えていない 場合があるため, 調査票回収時に特に確認が必 要である。

嗜好品は，骨量への直接的な影響のみではな く，個人のライフスタイルの推察も骨粗鬆症を 含めた成人保健指導のデータとして重要である ことから特に大項目とした。なお，飲酒に関し ては摂取頻度および 1 回当たりアルコール摂取 量の把握が成人保健指導上重要であるが，今回 の調査では現在の摂取頻度のみを尋ねることと した。

食生活に関する設問は若年期および現在の食 生活について明確に区別した欄を設けた。しか し，実際に栄養摂取量を調査するためには 3 日 間以上の食品摂取状況を細かく把握しなくては ならず，大集団を対象とした調査では正確性を 期し難い。従って，今回の設問には食生活の傾 向を把握するため，摂取頻度のみを問うことと した。なお，みそ汁など直接骨量には関係しな いと考えられる食品群の摂取状況もライフス夕 イルの把握および成人保健の指導資料として設 問項目に採用した。ダイエットも骨量減少に関 する危険因子として重要であるが，その程度や 回数の把握が困難なため, 体重減少が一定以上 （10kg 以上）あったもののみをダイエット歴 


\section{ありとした。}

住まいの状況に関する設問は，ライフスタイ ルの把握のためだけではなく，日本的な住宅環 境で「しゃがむ」動作が多くなり，その結果足 腰の筋力維持や骨量維持に働く可能性が考えら れたため特に設けた。

検診票は自記式とし, 検診の現場で記入漏れ や特に運動などで思い入れによる不記載などが ないか内容を確認することとした。

骨量検診の要となるのが骨量定量法による骨 量測定であるが, 現在実に様々な方法及び装置 があり，各医療機関毎に異なる装置を用いて異 なる部位を測定して判定を行っているのが現状 である。よって, 今回の共同研究では, 測定方 法, 装置, 測定対象部位の統一は特に行わない ことにした。しかし, これらの条件の違いに よって一般に, peak bone mass の出現時期や, 若年者平均骨量（YAM : Young Adult Mean） と各年齢層の平均骨量の比, また, 統計学的な 分布型に大きな違いが現れ，これらの条件が異 なる施設間では単純な比較は不可能であると考 えられる。そのため, 今回の調査では, 各施設 を受診した対象者毎にその測定值を, 同年噛平 均骨量に対する比および Zスコア, 並びに若 年者平均骨量に対する比および Zスコアに各 施設のスタンダードを用いて換算して検討する こととした。また，骨量評価では可能な限り腰 椎の $\mathrm{X}$ 線撮影を行い, 整形外科医が慈恵大式 分類による判定および椎体の圧迫骨折の有無の 判定も行うこととした。

体格測定は身長, 体重の測定を行う。体脂肪 は近年手軽に測定できるようになり，体格の評 価に有用であると考えられるが，簡便なイン ピーダンス法では再現性にやや難があることな どから今回の研究では統一した検査項目には採 用しなかった。

血液検査は, 骨の系統疾患の除外診断のため に, 血清 $\mathrm{Ca}, \mathrm{P}, \mathrm{Al}-\mathrm{P}$ の測定を必須項目とし た。個人もしくは集団の動的な骨代謝と関連が 強いとされるマーカーは，骨形成マーカーとし て血中オステオカルシン，骨吸収マーカーとし て尿中デオキシピリジノリンなどが代表的であ
る。また，女性においては性ホルモンが骨量の 維持に重要な役割を担うが, いずれも日内変動 や性周期による変動があり, 集団を対象とした 検診では測定值の解釈が難しい。今回の研究で は研究班での討議を経てオステオカルシンを測 定することとして，2 年目の検診で測定を実施 した。

\section{対象と方法}

各施設における女性の測定は松阪中央総合病 院にて428名（40～59歳, 平均51.7歳士標準偏 差5.4歳), 総合病院旭川厚生病院にて164名

(40 63歳, 平均 50.2 歳 \pm 5.6 歳), 平鹿総合病 院260名 (37 78歳, 平均51. 1歳 \pm 6.1 歳), 岩手 医科大学医学部衛生学公衆衛生学講座 358 名 (23 83歳, 平均59.4歳 9. 6歳) であり, 総計 では1,210名 (23〜83歳, 平均 53.7 歳 \pm 8.0 歳) で あった。対象者は各施設で行った骨粗鬆症検診 受診者であり，寝たきり者などを除く，通常の 日常生活を行えている者である。

骨量は先ず各施設で現有する DEXA 法によ る骨密度測定装置（旭川厚生病院：アロカ社 DXS-600にて非利き手側橈骨遠位端測定, 平 鹿総合病院：東洋メディック社 DTX-200にて 非利き手側橈骨遠位端測定）もしくは超音波法 による骨強度測定装置（松阪中央総合病院およ び岩手医科大学医学部衛生学公衆衛生学講座, ルナー社 A-1000 “Achilless”にて利き手側踵 骨測定）により測定，これを各施設で測定結果 判定に使用している年代別標準值を用いて YAM (Young Age Mean) matched \%および Zスコア, Age Matched \%およびZスコアを 算出, これらの数值で評価を行った。

採血は $\mathrm{Ca}, \mathrm{P}, \mathrm{ALP}$ およびオステオカルシン 測定を目的として行い, Ca，P，ALPは各施設 で分析した。オステオカルシンについては一般 的な医科施設では测定できないため, 採血後血 清分離，凍結したのち一括して外注した。

問診は受診者の自記式とし，受診時に回収し た。回収時には担当者がチェックし，なるべく 記載漏れが少なくなるよう留意した。 


\section{結 果 と考 察}

各施設別に年齢階級別の Age Matched Zscoreの分布をみると，松阪中央では全体に Z -score が低く, 平鹿総合ではやや高い。年齢 階級別では，岩手医大の40歳代でZ-score が 低く表現されている。また，Z-scoreの標準偏 差は平鹿総合で全体に大きく，また旭川厚生の 50 歳代も高い。逆に岩手医大の60歳代以降で小 さく表現されている。標本分布が正規分布して いれば Z-score の母平均 $\mu=0$, 母分散 $\delta^{2}=1$ になるので，標準值として用いられている平均 值および標準偏差の数值と地域住民の実態が あっていないものと考えられる。今回は各施設 の結果を標準化するため, Age matched Zscore について各施設別, 各年齢階級別にさら に Z 変換を行い，各施設毎にそれぞれの年齢 階級で Age matched Z-scoreの平均が0, 標 準偏差が 1 になるようにして以後の解析を行っ た。

体格と骨量では，松阪中央および平鹿総合で 体重と骨量間に比較的強い相関を認めたが（p $<1 \%)$ ，旭川厚生では相関傾向は弱かった。 身長では松阪中央で弱い相関を認めた（ $<<$ $5 \%$ ）が，他施設では特定の傾向は認めなかっ た。Body Mass Index（BMI）では体重と同様 の傾向を認めた。

骨粗鬆症検診では骨粗鬆症と診断されたこと があるため受診するという例がしばしば経験さ れるため，骨粗鬆症既往と骨量について検討し た。松阪および旭川で有意に既往あり群の Age matched Z-score が低下していた。平鹿および 岩手では明らかな差が認められなかった。施設 によっては骨粗鬆症の既往歴が受診行動に影響 をおよぼしているものと思われたが，各施設と も例数中に占める割合が低いため, 以降の解析 も骨粗秐症既往ありの者を含めて行うこととし た。

骨折既往と骨量では，松阪で骨折あり群でや やZ-score が低下していたが，全施設とも有 意差は認めなかった。40歳代，50歳代が対象の 多くを占め，完成された骨粗鬆症による骨折者
が少なく，また，日常生活を営める者を対象と していることによるものと考えられる。その他 既往歴では該当者は少なかったが，腎臓病，甲 状腺以外で骨量の低下傾向を認めた。自覚症状 と骨量では，最近 1 か月間での背中・腰の痛み ありの者は584名（平均年齢52.3歳 \pm 6.5 歳）い たが，そのZ-scoreは+0.03土0.97と特に低 下を認めず，大多数の例では腰痛症による症状 であると考えられた。身長が $2 \mathrm{~cm}$ 以上低く なったと答えた者は 232 名（平均年齢57.5歳士 7.1歳）いたが，Z-scoreでは0.02 0.96 と特 に低下は認められなかった。円背ありと答えた 者は263名（平均年齢54.8歳士7.8歳）いたが, やはり Z-scoreでは0.03土0.99と，低下を認 めなかった。

初潮年齢と骨量では，特に一定した傾向は認 めなかった。ただし，20歳以降（n=5）では Z-score はー0.32 0.63と低下がみられた。閉 経と骨量では，閉経群で Z-score がやや低い。 自然閉経者で閉経年齢とその後の経過年数でみ ると，50歳未満で閉経した者は50歳以降の閉経 者に比較して骨量が低く, 閉経後年数が経過し ても同様の傾向を示した。しかし婦人科手術に よる人工的閉経者では，自然閉経者と異なる傾 向を示した。

出産数と骨量では 4 人以上出産群で有意では ないがZ-scoreの低下傾向がみられた。

農業従事の有無では農業従事者で骨量がやや 高いが有意差は認めなかった。また，それぞれ の作業態様別でも特に関連は認めなかった。

戸外活動時間と骨量では，戸外活動が長いほ どZ-score が高く，30分以内程度群と 2 時間 以上群で Z-score に有意差が認められた。

過去の運動経験の有無では, 運動あり群で Z -score が高く, 特に 3 年, $4 \sim 6$ 年群で高值 を示し，中高年時の運動が骨量増加に有用であ ることが示唆される。現在の運動習慣では，運 動習慣ありと答えた者は302名おり（有効回答 中 $30.3 \%)$ ，運動習慣なしの者と比較し有意に Z-score が高く（p<5\%），また，週あたり運 動時間では240分以上の群で特に高值を示した。

喏好品では毎日飲酒群でZ-score がやや高 
いが（+0.21 $1.30, \mathrm{n}=32 ）$ 他群と有意差は 認めなかった。喫煙歴はほとんどの者がなく,

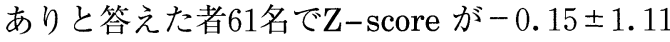
とやや低值傾向にあったが例数が少なく有意差 はなかった。

食生活では現在の牛乳，乳製品，豆腐，肉卵 類，小魚，魚介類および20歳頃の納豆，魚介類 で摂取頻度が多い群でZ-score が高值の傾向 を示した。10kg 以上減量した経験のある者は

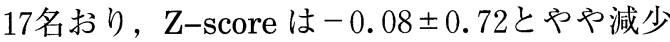
傾向を示した。室内の生活環境と骨量の関係で は，ベッド使用の有無および使用トイレ様式に よる違いは認められなかった。

オステオカルシンの有効測定例数は476名で あり, Age matched score とは有意の逆の相関 を示した $(\mathrm{r}=-0.152, \mathrm{p}<1 \%)$ 。また，年齢 とは正の強い相関を示した $(\mathrm{r}=+0.408, \mathrm{p}<$ $1 \%)$ 。自然閉経者で閉経後年数とオステオカ ルシンの関係についてみると, 特に閉経後 2 3 年で高值を示した。

\section{ま と め}

平成 9 年度は問診票を研究班で討議し作成し た。岩手医科大学医学部衛生学公衆衛生学講座 では超音波法を 1 次, DEXA 法を 2 次検査と

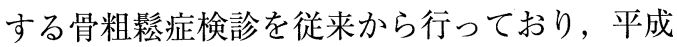
9 年度は従来, 講座で行っていたシステムと新 しい問診票を用いて検診を行った。

平成10年度は各施設で同一の検診票を用いて それぞれ検診を行った。検診終了後, 各分担研 究者によりデータが入力され, 研究代表者に送 られ解析が行われた。Age matched Z-score を 用いて年齢の影響および各施設の測定法の違い を標準化する予定であったが，施設別・年齢階 級別に Age matched Z-scoreがかなり異なっ て表現されたため，各施設別・年齢階級別に Age matched Z-scoreをさらにZ変換し, そ れぞれの階級で平均が 0 , 標準偏差が 1 と表現さ れるように標準化を行った。

各項目についての検討では，体格で特に体重 と骨量に正の相関を認めた。既往歴では骨粗鬆 症以外にも糖尿病, 肝臟病，リウマチ，胃手術
歴ありの者で骨量が低下傾向にあり, 要注意群 と考えられた。しかし骨折既往や腰痛, 円背の 有無は骨量と特に強い関連はなく，少なくとも 今回の対象年齢層では骨量低下状態の指標とは なりにくいものと思われる。女性では女性ホル モンが骨代謝に強く影響するが，今回の検討で は，初潮年齢や現在の月経状況と骨量との関連 は特に認められなかった。しかし，50歳未満で 自然閉経した群ではその後の骨量が低下傾向に あり, 注意を要する。出産数では 4 回以上で骨 量の低下傾向がみられるため, 多数回出産例で は骨量の経過観察が望ましい。運動状況では戸 外活動が 2 時間以上の群, 過去の運動経験あり 群，現在の運動習慣あり群でそれぞれ骨量が高 い。しかし，農作業従事群では動き回る作業と 答えた群でも特に骨量の増加傾向は認められな いことから，農業従事者においても日常の運動 習慣の獲得が望ましいものと考えられる。食生 活状況では主要なカルシウム摂取源である食品 の現在の摂取頻度の多い群で骨量が高い傾向に ある。生活環境では，布団および和式トイレ使 用者にしゃがむ動作が多く，骨量の維持に働く ものと期待したが，特に有意な差は認めなかっ た。しかし，これらの群では筋力の維持や生活 様式が床に近いことから骨折を来たすような転 倒数の減少につながる可能性があり, 今後さら に追跡したい。骨代謝マーカーとして測定した オステオカルシンでは自然閉経後 $2 \sim 3$ 年で特 に高值を示し，測定時点での骨代謝の状況を把 握するため有用であると考えられた。

検診票については，簡略化を心がけたが，一 部記載方法がわかりにくく，特定の項目で記入 漏れがみられた。また，このような記載方法の わかりにくさは検診の事後処理やデータベース 化の際に入力ミスを誘発しやすい。問診項目に は全てコード番号をあらかじめ付けておくなど の対策を今後行いたい。また，問診項目の簡略 化も一次予防に関する有力な情報以外の項目で 行いたい。例えば複数記載とした項目でほとん ど複数記載がみられない項目では, 集団の特性 を論ずる上では特に意味を成さないため，単一 事項のみの記載とすべきである。 